Graeco-Latina Brunensia 24/2019/ 1

https://doi.org/10.5817/GLB2019-1-14

Gillmeister, Andrzej (Ed.). (2018). Rerum Gestarum Monumentis et Memoriae: Cultural Readings in Livy. (208 p.). Warszawa: Uniwersytet warszawski. ISBN 978-83-943652-8-8.

\title{
Markéta Melounová
}

The presented collection of studies offers yet another view of Livy's treatment of Roman history. Although there is certainly a rich selection at hand in the field of Liviana, it can be stated that the contributions of the reviewed title bring in some interesting and, to a certain degree, innovative insights: The authors interpret Livy's work from the socio-cultural point of view, and, in several cases, examine the possible projection of the "Augustan perspective" onto Livy's account of the earliest Roman history and institutions. ${ }^{1}$

The collection consists of ten articles written in English or Italian, together with a general introduction in English that summarizes the content of the articles and presents what the authors mean by what they call "cultural reading".

The complementary material of the book is formed by a general index locorum from ancient sources and a general bibliography. Moreover, the articles of A. Mastrocinque and A. A. Kluczek are supplemented with several pages of coloured pictures, mostly of coins.

The collection is presented as "the aftermath of a symposium" that took place at the Institute of History of the University of Zielona Góra, Poland, in May 2017 (p. 7). Individual articles do not lack authors' affiliation; however, some brief additional information on them would be appreciated.

The first article, Book Burning in Livy: Text and Context, by Daniel Sarefield, analyses Livy's references to the cases, when writings that had been recognized by the authorities as danger-

1 "The shadow of the creator of the principate penetrates the majority of the articles." (p. 8). ous for the Roman state were publicly burnt. The article provides a well-articulated introduction and conclusions. The author "seeks to examine the evidence for the practice of book burning and state censorship in the work of the historian Titus Livius" (p. 13). First, he lists the cases of burning of the harmful political and religious writings during the Middle Republic present in Livy's work. Afterwards, he strives to compare these situations to the period of Livy's own lifetime and that immediately before (Late Republic, Augustan Principate). Unfortunately, here we find only general examples (burning of some kind of books) less relevant to the examined issue or the comparison of the two periods, such as debt records (p. 26), incriminating political testimonies (p. 21, n. 23, p. 25) or even poetry (pp. 22-23). The burning of infamatory writings or certain shady prophecies in Augustus' time (pp. 29-31) is a much better parallel to the earlier Republican custom of destroying potentially dangerous writings described by Livy. Sarefield's assumption that "Livy's presentation of the early practice of book burning by the Roman state appears to be influenced by his experience with this practice in his own contemporary world" (p. 13) can hardly be proven given the extant evidence, of which Sarefield is well aware (p. 32).

In the second article, Livy and the Kingdom of Servius Tullius: Notes on the Foundation of the Aventine Cult of Diana (Liv. 1, 45), Beatrice Poletti presents a detailed examination of the "aetiological" story illuminating the specifics of Diana's cult on the Aventine Hill (the sacrifice of the prodigious Sabine heifer by a cunning Roman). Poletti sets the story into the appropriate context, i.e. the 
specifics of the Roman cult of Diana in contrast to that of other famous centres of the goddess in Latium, monetary reflexions of the tale, the versions of the story described by Valerius Maximus and Plutarch, the possible role of the story in political propaganda of the families of Postumii Albini and Cornelii, and its significance in the frame of Livy's portrait of the king Servius Tullius. Poletti convincingly argues that Livy's preference for the version where the king does not play an active role in the deceitful sacrifice is consistent with his ambivalent account of Servius Tullius: Livy's Servius is "an opportunist", but "he is not endowed with malicious cunning” (p. 46), his reign was beneficial for Rome just like the kingdom was a necessary step towards "liberty".

Patricia A. Johnston contributed to the volume by a study named Livy versus Vergil: The Beauty of Cattle, and How the Sibylline Books Came to Rome. The study offers an interesting comparison between Vergil's and Livy's rendition of the earliest events in Latium, the story of Hercules and Cacus, Evander and Carmenta, and Aeneas' arrival in Italy. Johnston points to the marginal importance of the Trojan escapade in Livy, as contrasted with Vergil. She also proposes the diverse significance of the Cuman Sibyl in both writers: in Vergil, she is already present in Italy when Aeneas arrives; however, Livy, despite his many records of Romans consulting the Sibylline books, apparently implies her later arrival. Despite the author's inspiring insights, the article lacks a due introduction, while more thorough conclusions could have perhaps been presented, too. There is also another minor issue: Johnston claims (pp. 59, 61) that, according to Livy, the Romans consulted the Sibylline books for the first time in 399 BCE. Livy does not explicitly say that, he only states that the Romans performed the lecisternium for the first time. ${ }^{2}$

2 Cuius insanabili perniciei quando nec causa nec finis inveniebatur, libri Sibyllini ex senatus consulto aditi sunt. Duumviri sacris faciundis, lectisternio tunc pri-
The third study, Livio e i prodigi, by Claudia Santi, focuses on the prodigies, i.e. divine warnings pointing to the violation of the world order that necessitated expiatory rituals. Santi neatly analyses selected cases of prodigies and expiatory rituals recorded by Livy for the age of the kings, the Early Republic and the Second Punic war. By comparing Livy's careful treatment of prodigies with Sallust's sceptical laments over the moral decline and religious negligence of his time, Santi reveals an "Augustan" attitude toward this aspect of Roman religion in Livy's style. This is because the prodigies became increasingly important under the first princeps not only in the context of his restoration policy, but also in his personal regard.

Attilio Mastrocinque's Livio, la pace di Apamea e la monetazione dell'Asia Minore is a re-examination of his article from 1984, based on the updated numismatic evidence. Mastrocinque uses the testimony of coins to verify Livy's and Polybius' accounts of the political consequences that the peace of Apamea, concluded by the Romans with the Syrian king Antiochus III in 188 BCE, had for different cities in Asia Minor. He seeks to clarify whether the cities that had been tributary to Attalus I remained tributary to Eumenes II, whereas those cities that either had not been tributary to the king of Pergamum or that sided with the Romans became free. The author performs a detailed analysis of the evidence; nevertheless, the conclusions could have been more concise.

Livy's reference to the monument of the shewolf with infant Romulus and Remus that the Ogulnii brothers erected ad ficum Ruminalem during their aedilship (296 BCE; Liv. 10,23,11) is a starting point for the sixth study, Conditores Urbis Romae, Livy and Roman Coins, by Agata A. Kluczek. This study, too, lacks a concise introduction and summary. What is more, it is probably a version of the author's another study

mum in urbe Romana facto... (Liv. 5,13,6; highlighting by MM). 
written in Polish, whose title, as indicated in the bibliography, is exactly the same (Conditores Urbis Romae, Liwiusz i rzymskie numizmaty, In Gremium 12, 2018, pp. 61-80). Kluczek first deals with the iconographic type of the she-wolf with children as a rather rare motif that was introduced on the first Roman silver didrachmas before the middle of the $3^{\text {rd }}$ century BCE, and points to their later imitations (the historicizing coin issues minted for Domitianus as caesar; the image of the Mattei sarcophagus from the $3^{\text {rd }} \mathrm{c}$. CE). Afterwards, she deals with the problem of identification and exact location of the Ogulnii monument in the context of lupa monuments attested by ancient authors in Rome. The location remains dubious due to the unclear location of ficus Ruminalis; Kluczek identifies Livy's ficus with that of the Roman Forum next to the comitium. She also examines Livy's use of the word conditor/-es in relation to the founding brothers Romulus and Remus, and the renewed importance that the founding tradition gained under the usurper Maxentius at the beginning of the $4^{\text {th }}$ century CE. Finally, Kluczek convincingly argues that Livy conveys Augustan adjustments of the tradition in his rendition of the founding myth including the rehabilitation of Remus.

Katarzyna Balbuza, in a study named Livy and the Pignora Imperii. The Historian from Patavium as a Eulogist of the Idea of the Eternity of Rome, investigates the passages from Livy's histories, where pignora, i.e. the pledges of the eternal existence of the City, are mentioned. In this way, she proves the heavy dependence of Livy's account of these on the ideology of Augustan Principate.

I appreciate Tiziana Carboni's article named Livio come fonte per la conoscenza dei mandata for its well-conceived methodology. The author focuses on the problem of terminological inaccuracy and inconsistency of ancient narrative sources using the example of Livy's application of the term mandata. The definition of the term, which is usually being associated with a reality of the Roman Empire, is followed by a precise analysis of Livy's references (a table included), which demonstrates two general meanings the term has for Livy - a message and an official order, either in oral or written form.

Michał N. Faszcza's study named Livy and the Celts represents yet another contribution to the discussion of ancient authors' reception of the Celts. Faszcza's examination is well-founded and brings into consideration several important issues, such as the problem of defining ethnicity, especially the "Celticity", and the different perspectives of ancient authors and modern researchers to the term. The results of the research are far from surprising: Livy mostly follows ancient stereotypes; his image of the Celts is consistent with the Roman concept of "the others" - they are enemies that endanger the culturally superior Roman civilization.

The presented volume is concluded by László Takács' article named Livy and Servius: Which Version of Rome's Early History was Read in the Classroom in Late Antiquity? Using the probe method, Takács intends to prove that, even though Livy was known and even quoted by Servius' commentary, the commentary tended to prefer other historical interpretations. Takács selected three stories from the age of the kings (Romulus and Hersilia, Mettius Fufetius' punishment, Lucretia) for his examination. By comparing the different extant versions of these and by determining the possible motives of the authors for choosing particular versions of the stories (the necessity to cope with some Augustan parallels in the case of Livy?), he argues for the fact that Servius' commentary tends not to follow Livy on purpose, since Livy's treatment of Roman history had long come out of fashion at the time. It is unfortunate that this study, too, fails to provide more general conclusions.

As demonstrated above, the topics of the studies included are highly varied and, at first glance, seem rather disparate. There is, 
however, a common ground shared by all the be studied, and to show new aspects of his hiscontributions, that is, the effort to introduce torical writing. In this effort, I regard the renew perspectives, from which Livy's work can viewed title to be successful.

Mgr. et Mgr. Markéta Melounová, Ph.D. / marmel@mail.muni.cz

Department of Classical Studies

Masaryk University, Faculty of Arts

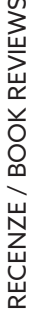

Arna Nováka 1, 60200 Brno, Czech Republic 